\title{
In vitro evaluation of antioxidant, anticancer, and antiviral activities of exopolysaccharide from Streptomyces hirsutus NRC2018
}

\author{
Mohamed E. El Awady ${ }^{*}$, Mohamed A. Nasr Eldin², Heba M. Ibrahim³ ${ }^{3}$ Mohamed E. Al Bahnasy², Samir H. Abdel Aziz ${ }^{2}$ \\ ${ }^{1}$ Department of Microbial Biotechnology, National Research Centre, Giza, Egypt. \\ ${ }^{2}$ Botany and Microbiology Department, Faculty of Science, Benha University, Benha, Egypt. \\ ${ }^{3}$ Genetics Department, Faculty of Agriculture, Cairo University, Giza, Egypt.
}

\section{ARTICLE INFO \\ Received on: 19/01/2019 \\ Accepted on: 26/08/2019 \\ Available online: 04/11/2019}

\section{Key words:}

Exopolysaccharide, production, Streptomyces hirsutus, antioxidant, anticancer, antiviral.

\begin{abstract}
An exopolysaccharide Exopolysaccharide (EPSNC2) produced from marine Streptomyces hirsutus NRC2018 which was isolated from marine sediments at North Coast, Egypt with accession number MK050544. EPSNC2 was a $\beta$-type heteropolysaccharide contained uronic acid $(72.73 \%)$ with no sulfate groups and overall average molecular weight (Mw) $4.25 \times 10^{5} \mathrm{~g} / \mathrm{mol}$. The monosaccharide composition was glucuronic:galacturonic:glucose:mannose:arabinose with molar ratio 1.2:0.6:0.1:0.2:0.1, respectively. EPSNC2 was subjected to antioxidant, anticancer, and antiviral in vitro tests, showed high 1, 1-diphenyl-2-picrylhydrazyl free radical scavenging activity whereas, the maximum antioxidant activity was $95.9 \%$ at $1,500 \mu \mathrm{g} / \mathrm{ml}$ after 120 minutes and the $\mathrm{IC}_{50}$ value was $158.5 \mu \mathrm{g} / \mathrm{ml}$. Also, EPSNC2 had the ability to scavenge $\mathrm{H}_{2} \mathrm{O}_{2}$ and the maximum activity was $75.6 \%$ with an estimated $\mathrm{IC}_{50}$ value $501.2 \mu \mathrm{g} / \mathrm{ml}$. Furthermore, EPSNC2 showed a reducing power activity as well as a metal chelating activity in a dose dependant manner and the activity reached $98.5 \%$ at $1,000 \mu \mathrm{g} / \mathrm{ml}$. EPSNC2 had a significant and specific anticancer effect on CaCo-2 cell line without any effect on other cell lines and the $\mathrm{IC}_{50}$ was estimated to be $295.1 \mu \mathrm{g} / \mathrm{ml}$. Our results regarding the antiviral activity against Herpes Simplex virus type 1 (HSV-1), Hepatitis A virus, and Coxsackie B-4 were $84.9 \%, 20.3 \%$, and $45.4 \%$, respectively at $125 \mu \mathrm{g} / \mathrm{ml}$ with no activity against adenovirus. Therefore, the $\mathrm{EC}_{50}$ value against the enveloped virus HSV-1 was $32.4 \mu \mathrm{g} / \mathrm{ml}$.
\end{abstract}

\section{INTRODUCTION}

Exopolysaccharides (EPSs) are microbial primary metabolites biopolymers produced and transferred outside the cells. They are composed of monosaccharide units linked with $\alpha$ - or $\beta$-glycosidic linkage. EPSs can be classified into homo- or hetero- as well as neutral, basic, or acidic polysaccharides based on monosaccharide content, organic and inorganic substituents (Sutherland, 1997). Microbial EPSs showed diversity in physicochemical properties due to differences in monosaccharide composition and sequence, type of linkage and polymerization, and branching degree. This diversity of characteristics has drawn attention to the industrial values of EPSs in different fields (Patel et al., 2010).

${ }^{*}$ Corresponding Author

Mohamed E. El Awady, Department of Microbial Biotechnology, National Research Centre, Giza, Egypt.E-mail: mohamed elawady@yahoo.com
In recent decades, marine bacteria have been an interesting field in biomedical research since they produce many novel EPSs of great valuable bioactivity such as anticancer (Sun et al., 2013), anti-inflammatory (Jones et al, 2014), immunomodulatory (Tang et al., 2015), antithrombotic, hypoglycemic, hypocholesterolemic, antiviral (Rincão et al., 2012), and antioxidant (El-Newary et al., 2017). Streptomyces, a Gram-positive bacterium, is well-known as an important industrial microorganism for its natural derived metabolites production as EPS production (Beshay et al., 2009; Manivasagan et al., 2013).

Cancer is a set of diseases involving cell growth abnormalities with the ability to spread through blood or lymphatic vessels and invade other parts (metastasis). Cancer is the second disease that causes mortality worldwide with about $15.7 \%$ deaths and about 14.1 million new cases occurring annually. Over 100 types of cancer had been diagnosed to affect humans. Colon cancer, also known as colorectal and bowel cancer, is an abnormal overgrowth of epithelial cells lining the colon or rectum. Every 
year more than 1 million people have colorectal cancer and it was the second most common type in women about $9.2 \%$, the third in men about $10 \%$, and the fourth most common causing cancer death globally (Forman and Ferlay, 2014). Treatment of cancer represents a large obstacle for scientists and physicians because these remedies lack specificity against cancerous cells leading to damage of healthy cells and a lot of serious side effects of patients. It is, therefore, necessary to discover and develop other types of highly efficient and specialized treatment for cancer cells to be safe on healthy ones (Sarkar et al., 2013).

Herpes simplex virus type-1 is an enveloped virus that belongs to the family Herpesviridae, subfamily alpha-herpesvirinae. Herpesviridae has been divided into alpha-, beta-, and gamma subfamilies with over 100 different members, eight of them are known as human pathogens. Herpes Simplex virus type 1 (HSV-1) mediates its entry into cells via interaction between viral envelope glycoproteins with cell surface receptors heparan sulfate, nectin-1,2 and herpesvirus entry mediator (Akhtar and Shukla, 2009). Herpesviridae family viruses cause diseases varying in severity between mild to more severe. Alphaherpesvirinae member HSV-1 causes cold sores and encephalitis and it was reported that there is an indirect link between that virus and Alzheimer's disease while, HSV-2 causes genital disease, encephalitis, and infections of newborns (Whitley and Roizman, 2001). HSV-1 may persist latent in trigeminal ganglia, whereas HSV-2 persists in sacral ganglia and the reactivation occurs during immunodeficiency (Whitley and Roizman, 2001).

Therefore, the aim of this work was to explore the potential biological activities of a new safe microbial exopolysaccharide possessed by Streptomyces hirsutus NRC2018. Exopolysaccharide (EPSNC2) was evaluated for its antioxidant, anti-cancer, and antiviral activities.

\section{MATERIALS AND METHOD}

\section{Sampling and isolation of streptomycetes}

Samples were collected during summer 2016 from marine sediments from North Coast, Egypt. Samples were serially diluted according to Hayakawa and Nonomura (1987), and plated on starch nitrate agar medium containing (g/l): starch 10.0, $\mathrm{K}_{2} \mathrm{HPO}_{4} 1.0, \mathrm{MgSO}_{4} \cdot 7 \mathrm{H}_{2} \mathrm{O} 0.5, \mathrm{NaCl} 0.5, \mathrm{KNO}_{3} 2.0, \mathrm{CaCO}_{3} 2.0$, $\mathrm{FeSO}_{4} .7 \mathrm{H}_{2} \mathrm{O} 0.01$, and agar 20.0, which was dissolved in $750 \mathrm{ml}$ seawater then topped to $1 \mathrm{~L}$ with $250 \mathrm{ml}$ distilled water, $\mathrm{pH}$ adjusted to 7.0 (Waksman, 1961). The streptomycete isolate was selected and picked up based on the morphological features of colonies.

\section{Identification of streptomycete isolate}

The isolate was identified according to morphological, physiological, and biochemical features (Goodfellow et al., 1987; Kutzner, 1976; Shirling and Gottlieb, 1966; Szabó et al., 1975; Tresner and Backus 1963). Also, molecular identification was performed by $16 S$ rRNA gene sequencing. The bacterial genome was isolated and $16 S$ rRNA gene was amplified using polymerase chain reaction technique using the following primers $\mathrm{F}\left(5^{\prime}\right.$ GAGTTTGATCCTGGCTCAG 3) and R(5'GGTTACCTTGTTACGACTT 3') based on Gardes and Bruns (1993) method. Sequencing was done using kit of Big Dye terminator cycle sequencing (Applied Biosystems, USA).
Products of sequencing were analyzed on a model Applied Biosystems 3730XL automated DNA sequencing system (Applied Biosystems, USA). The resulted $16 S$ rRNA sequence was submitted to GenBank database and compared with the other sequences in https://www.ncbi.nlm.nih.gov/ using the BLAST program. The sequence of other bacterial strains with the most similarity to the $16 S$ rRNA gene of our isolate was selected and aligned for making the suitable phylogenetic tree. Then, $16 \mathrm{~S}$ rRNA sequence was deposited in the DDBJ/EMBL/GenBank databases with accession number MK050544.

\section{EPS production}

Streptomyces isolate was inoculated into production medium containing (g/l) Glucose 10.0, Tryptone 5.0, Yeast extract 5.0, $\mathrm{K}_{2} \mathrm{HPO}_{4} 3.0, \mathrm{NaCl} 3.0, \mathrm{KH}_{2} \mathrm{PO}_{4} 1.0, \mathrm{MgSO}_{4} .7 \mathrm{H}_{2} \mathrm{O} 0.5$, $\mathrm{CaCO}_{3} 0.5$ dissolved in $750 \mathrm{ml}$ seawater and topped to $1 \mathrm{~L}$ by distilled water and adjusted to $\mathrm{pH} 7$ (Manivasagan et al., 2013) then incubated at $28^{\circ} \mathrm{C}$ for 5 days at $120 \mathrm{rpm}$. After incubation, the medium was centrifuged at 5,000 rpm for 30 minutes, the supernatant mixed with Trichloroacetic acid (TCA) (10\%) and left overnight at $4 \mathrm{C}$. Then, centrifuged at 5,000 rpm for 20 minutes to remove the protein. The supernatant $\mathrm{pH}$ was neutralized to 7 with $\mathrm{NaOH}$ solution (Liu et al., 2010). The EPSs containing solution was collected and mixed with four volumes of ethanol $(95 \%)$, left it overnight at $4^{\circ} \mathrm{C}$. The precipitated EPSs were separated by centrifugation at 5,000 rpm for 20 minutes and redissolved in deionized water and dialyzed three times $(1 \mathrm{~L} \times 3)$ using dialysis tubing (MWCO 2000) for 48 hours. For purification and major fraction determination, absolute cold ethanol was added in 1, 2, 3, and 4 volumes gradually and the precipitated EPS was collected up to date. The major fraction obtained by one volume was dialyzed against distilled water for 72 hours, washed twice using acetone. Then, dehydrated by ether, dried at $40^{\circ} \mathrm{C}$, and coded as EPSNC2 (Shene et al., 2008).

\section{Homogeneity and molecular mass of EPSNC2}

The mass average molar mass $(M w)$ of EPSNC2 was determined used high-performance gel permeation chromatography (HPGPC, Agilent 1100 Series System, Hewlett-Packard, Germany) with refractive index (RI) detection (You et al., 2013). The number average molar mass (Mn) was determined and polydispersity index (PI) was calculated from $(\mathrm{Mw} / \mathrm{Mn})$ ratio.

\section{Monosaccharide composition analysis}

EPSNC2 was subjected to complete acid hydrolysis with formic acid $(88 \%)$ at $100^{\circ} \mathrm{C}$ for 5 hours. High-performance liquid chromatography (HPLC, Agilent Pack, serics1, 200), equipped with Aminex carbohydrate HP-87C column $(300 \times 7.8 \mathrm{~mm})$ was applied for monosaccharide composition and calculation of molar ratio (Randall et al., 1989).

\section{Fourier-transform infrared spectroscopy (FTIR)}

Dried EPSNC2 (2 mg) was mixed with $200 \mathrm{mg}$ $\mathrm{KBr}$ powder then pressed to form a pellet of $1 \mathrm{~mm}$. FTIR spectrum was measured in the range between 400 and 4,000 $\mathrm{cm}^{-1}$ using FTIR-UNIT Bruker Vector 22 Spectrophotometer (Brock-Neely, 1957). 


\section{Sulfate and uronic acid content determination}

EPSNC2 was subjected to complete acid hydrolysis with formic acid $(88 \%)$ at $100^{\circ} \mathrm{C}$ for 5 hours. The sulfate was estimated by the turbidity method using Barium Chloride-Tween 80 reagent according to Dodg=son and Price (1962). The content of uronic acid was determined using the $m$-hydroxybiphenyl colorimetric method at $525 \mathrm{~nm}$ (Filisetti-Cozzi and Carpita, 1991).

\section{Evaluation of EPSNC2 antioxidant bioactivity}

\section{$D P P H$ radical scavenging activity}

The 1, 1-diphenyl-2-picrylhydrazyl (DPPH) radical scavenging activity was determined according to Brand-Williams et al. (1995). Different concentrations of EPSNC2 (100, 300, 500, 1,000 , and $1,500 \mu \mathrm{g} / \mathrm{ml}$ ) were added to $2 \mathrm{ml}$ of DPPH solution. Then, left in dark for 10, 30, 60, and 90 minutes at $517 \mathrm{~nm}$ using UV-Visible spectrophotometer. The DPPH scavenging activity was calculated from the following equation:

Scavenging ability $(\%)=\left(A_{517 \text { of control }}-A_{517 \text { of sample }} / A_{517 \text { of control }}\right) \times 100$

\section{Hydrogen peroxide scavenging activity}

According to Ruch et al. (1989), different concentrations of EPSNC2 (200, 400, 600, 800, 1,000, and 1,500 $\mu \mathrm{g} / \mathrm{ml})$ were mixed with $40 \mathrm{mM}$ hydrogen peroxide solution in $50 \mathrm{mM}$ of phosphate buffer solution ( $\mathrm{pH} 7.4)$. The results were measured at different periods $(15,30,45$, and 60 minutes) against phosphate buffer as a blank and at $230 \mathrm{~nm}$ using UV-Visible spectrophotometer. $\mathrm{H}_{2} \mathrm{O}_{2}$ scavenging activity was calculated as follows:

Scavenging ability $(\%)=\left(A_{230 \text { of control }}-A_{230 \text { of sample }} / A_{230 \text { of control }}\right) \times 100$

\section{Reducing power (RP) activity}

EPSNC2 concentrations $(400,600,800$, and 1,000 $\mu \mathrm{g} /$ $\mathrm{ml}$ ) were added to $2.5 \mathrm{ml}$ of $0.2 \mathrm{M}$ phosphate buffer ( $\mathrm{pH} 6.6$ ) and $2.5 \mathrm{ml}$ potassium ferricyanide $\left(\mathrm{K}_{3} \mathrm{Fe}(\mathrm{CN})_{6}\right) 1 \% \mathrm{w} / \mathrm{v}$ and incubated at $50^{\circ} \mathrm{C}$ for 20 minutes then trichloroacetic acid $(2.5 \mathrm{ml}) 10 \% \mathrm{w} / \mathrm{v}$ was added. Then, mixture was centrifuged at 3,000 rpm for 10 minutes and the supernatant mixed with $2.5 \mathrm{ml} \mathrm{H}_{2} \mathrm{O}$ and $0.5 \mathrm{~mL}$ of $\mathrm{FeCl}_{3}(0.1 \% \mathrm{w} / \mathrm{v})$. The absorbance of colored complex was measured at $700 \mathrm{~nm}$ (Oyaizu, 1986).

\section{Metal chelating activity}

The chelating activity was detected using Dinis et al. (1994) method by mixing $0.1 \mathrm{~mL}$ of EPSNC2 solution with concentrations $(400,600,800$, and $1,000 \mu \mathrm{g} / \mathrm{ml})$ with $0.5 \mathrm{ml}$ of $0.2 \mathrm{mM}$ ferrous chloride; then $0.2 \mathrm{ml}$ of ferrozine $(5 \mathrm{mM})$ was added and the mixture incubated for 10 minutes at room temperature until red color complex was formed and then measured at $562 \mathrm{~nm}$. The activity of metal chelating was calculated according to the following equation:

Metal chelating activity $(\%)=\left(A_{562 \text { of control }}-A_{562 \text { of sample }} / A_{562 \text { of control }}\right) \times 100$

\section{Assessment of antitumor activity}

Cell line and culture

Human colorectal adenocarcinoma cell line ( $\mathrm{CaCo}-2)$, human hepatocellular carcinoma cell line (HepG2), human breast adenocarcinoma cell line (MCF-7), and human lung adenocarcinoma cell line (A-549) were obtained from Tissue Culture Unit, Holding Company for Biological Products and Vaccines (VACSERA) at Giza, Egypt. Cells were cultured in RPMI 1640 medium supplemented with $10 \%$ fetal bovine serum, $1 \%$ Glutamine, and 1\% Penicillin/Streptomycin and incubated at $37^{\circ} \mathrm{C}$ in $5 \% \mathrm{CO}_{2}$ humidified incubator.

\section{Cytotoxicity/Viability assay}

The cytotoxicity of EPSNC2 was evaluated through the MTT viability assay (Mossman et al., 1983). The cancer cells incubated with different concentrations of EPSNC2 $(7.8-500 \mu \mathrm{g} /$ $\mathrm{ml}$ ) in a 96-well micro-plate while, control was incubated with RPMI 1640 media without EPSNC2 for 24 hours at $37^{\circ} \mathrm{C}$, with $5 \%$ $\mathrm{CO}_{2}$. Cells were checked for any physical signs of toxicity, e.g. rounding, partial, or complete loss of the monolayer, cell granulation, or shrinkage. Then, $20 \mu \mathrm{l}$ of MTT (BIO BASIC CANADA INC) solution ( $5 \mathrm{mg} / \mathrm{ml}$ dissolved in PBS) was added to the cells for 5 minutes then $200 \mu \mathrm{l}$ of DMSO was added to dissolve formazan and then removed and the cells were washed. The absorbance was measured at $560 \mathrm{~nm}$ using a micro-plate ELISA reader. All tests were established in triplicate and averaged. The cell viability was calculated as follows:

$$
\left[1-\left(\mathrm{O}_{\mathrm{D}} \mathrm{D}_{\text {test }} / \mathrm{O} \cdot \mathrm{D}_{\text {control }}\right)\right] \times 100 \%
$$

\section{Assessment of antiviral activity}

Cell line and Cytotoxicity assay

African green monkey kidney epithelial (VERO) cell line was purchased from Tissue Culture Unit, VACSERA, Giza, Egypt. It was cultured in MEM-EARLE's medium (VACSERA, Egypt) enriched with $2 \%$ fetal bovine serum and incubated with serially diluted concentrations of EPSNC2 $(15.65,31.25,62.5,125,250$, and $500 \mu \mathrm{g} / \mathrm{ml}$ ) for up to 48 hours in $5 \% \mathrm{CO}_{2}$ at $37^{\circ} \mathrm{C}$. Cytotoxicity was determined using the MTT viability assay (Mossman et al., 1983). The half-maximal cytotoxic concentration $\left(\mathrm{IC}_{50}\right)$ and the minimum non-toxic concentration were calculated.

\section{Viruses and evaluation of antiviral activity}

The cytopathic effect of Herpes Simplex virus type 1 (HSV-1), Adenovirus, Hepatitis A virus (HAV), and Coxsackie B4 virus (Microbiology Department, Faculty of Medicine for girls, Al-Azhar University, Egypt) were tested on VERO cells and the half-maximal viral cytopathogenicity concentration was estimated using MTT method. Equal volume $(1: 1 \mathrm{v} / \mathrm{v})$ of three dilutions of EPSNC2 $(31.25,62.5$, and $125 \mu \mathrm{g} / \mathrm{ml})$ were incubated with the half-maximal viral cytopathogenicity concentration of viruses for 1 hour. $100 \mu \mathrm{l}$ of viral/sample suspension was added to $1 \times 10^{5}$ cells which were cultured in $200 \mu \mathrm{l}$ MEM media per well in a 96-well micro-plate then incubated at $37^{\circ} \mathrm{C}$ with $5 \%$ $\mathrm{CO}_{2}$ humidity for 24 hours until either viral cytopathic effect or antiviral activity of EPSNC2 was obtained. According to MTT viability assay (Pauwels et al., 1988), optical density was measured at $560 \mathrm{~nm}$ and the background was subtracted at $620 \mathrm{~nm}$. The experiment was carried out in triplicate. The concentration which inhibits $50 \%$ of viral cytopathic effect $\left(\mathrm{EC}_{50}\right)$ was determined. 


\section{Statistical analysis}

Graph Pad InStat version 2 software was used for analyzed of all results. All graphs were plotted using the Graph Pad Prism version 8 . Results were considered statistically significant with $p$ values $<0.05$.

\section{RESULTS AND DISCUSSION}

\section{Isolation and identification of EPS producing Streptomycetes strain}

The streptomycete strain was isolated from the sediments of the Mediterranean Sea, North Coast, Egypt. The isolate was taxonomically identified morphologically, biochemically, and physiologically. Streptomycete strain was confirmed using $16 \mathrm{~S}$ rRNA molecular identification. Table 1 shows the morphological, biochemical, and physiological features of the isolate. The isolate had a grayish color of spore mass with no melanin and diffusible pigment production. Also, it showed a variety in the utilization of different sugars as a carbon source. Whereas, the spore chain was spiral and spiny spore surface as obtained in Figure $1 \mathrm{a}$ and $\mathrm{b}$. The partial analysis of NC2 isolate $16 \mathrm{~S}$ rRNA gene and its comparison with the data included in GenBank proved that the isolate had $100 \%$ homology with $S$. hirsutus and gave an identification symbol NRC2018 with accession number MK050544.
The evolutionary history of the tree was inferred using the Neighbor-Joining method. The optimal tree with the sum of branch length $=0.00511422$ is shown. The tree is drawn to scale, with branch lengths in the same units as those of the evolutionary distances used to infer the phylogenetic tree. The evolutionary distances were computed using the Maximum Composite Likelihood method and are in the units of the number of base substitutions per site. The analysis involved 10 nucleotide sequences. All ambiguous positions were removed for each sequence pair. There were a total of 1,372 positions in the final dataset. Evolutionary analyses were conducted in MEGA X.

\section{EPS production, purification, and chemical characterization}

After 5 days of incubation in fermentation medium (Manivasagan et al., 2013), EPS $10 \mathrm{~g} / \mathrm{l}$ of culture media was isolated and the major fraction was obtained by addition of one volume absolute ethanol and named EPSNC2. The novel EPSNC2 was subjected to chemical analysis which proved that it contains $72.73 \%$ uronic acid and no sulfate content. Furthermore, monosaccharide composition and molar ratio which were determined by HPLC showed that EPSNC2 consisted of glucuronic acid: galacturonic acid: glucose: mannose: arabinose with molar ratio 1.2: 0.6: 0.1 : 0.2: 0.1 , respectively, which meant that EPSNC2 is a highly acidic heterogeneous polysaccharide.

Table 1. Morphological, physiological, and biochemical characteristics of NC2 isolate.

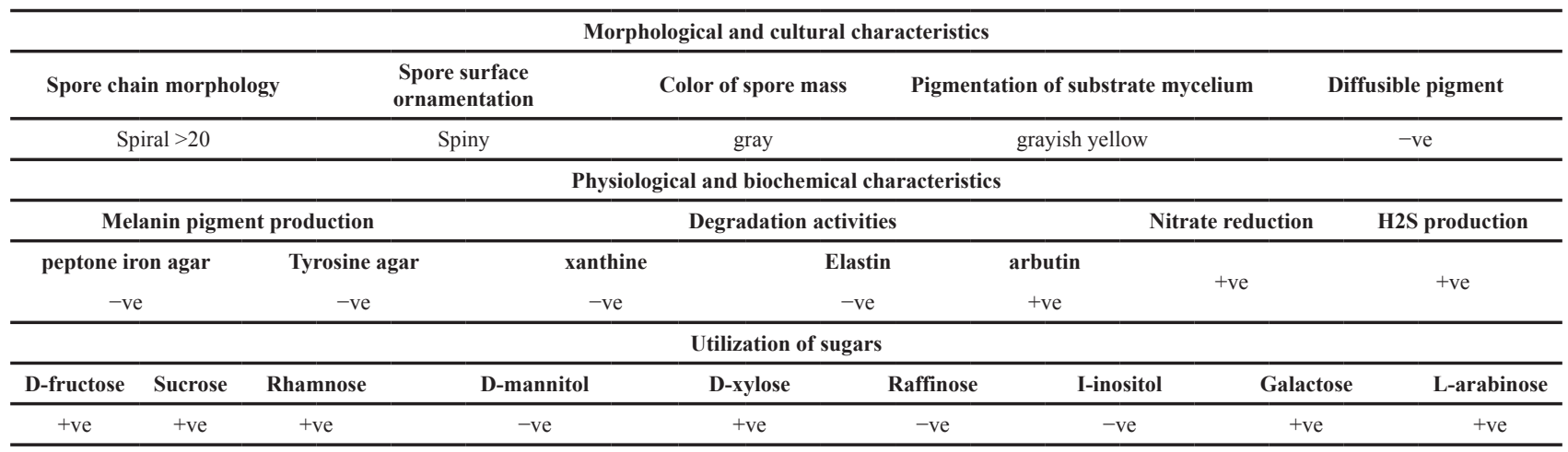
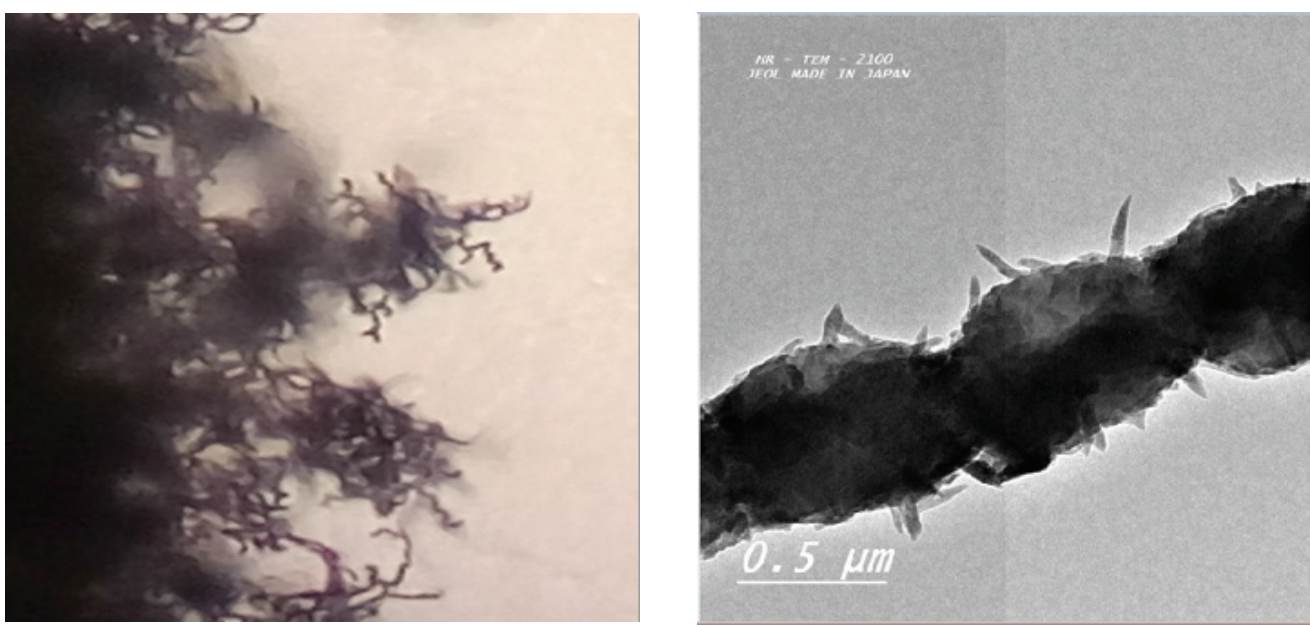

Figure 1. (a) Photomicrograph showing spiral aerial hyphae. (b) TEM micrograph showing spiny spore surface. 


\section{Molecular weight determination}

The mass average molar mass $(M w)$ and the number average molar mass $(\mathrm{Mn})$ were $4.25 \times 10^{5} \mathrm{~g} / \mathrm{mol}$ and $2.71 \times 10^{5} \mathrm{~g} /$ mol, respectively, as shown in Figure 2. While the PI which was calculated by $\mathrm{Mw} / \mathrm{Mn}$ ratio was 1.57 . Therefore, it is noted that EPSNC2 has a high molecular weight. These results are consistent with what has been published that Mw of EPSs between 10 and 6,000 kDa (Xie et al., 2010).

\section{FTIR spectroscopy analysis}

FT-IR spectrum showed patterns which are confirmatory for EPSNC2, as shown in Figure 3. A broad peak at 3,430.74 $\mathrm{cm}^{-1}$ for $\mathrm{OH}$ stretching vibration (Kavita et al., 2014) and weak $\mathrm{CH}$ stretching bands were obtained at 2,961.16, 2,928.38, and $2857.99 \mathrm{~cm}^{-1}$. The peak at $1,673.91 \mathrm{~cm}^{-1}$ was attributed to $\mathrm{C}=\mathrm{O}$ group stretching vibration as a result of the presence of the carboxylate group of uronic acid (Ahluwalia and Goyal, 2005; Lillo et al., 2014). While, the ß-pyranose structure was proved by the existence of $837.91 \mathrm{~cm}^{-1}$ band (Cheng et al., 2008) and $1,129.12$ and $1,107.9 \mathrm{~cm}^{-1}$ peaks which were referred to $\mathrm{C}-\mathrm{O}-\mathrm{C}$ and C-O groups (Vijayabaskar et al., 2011).

\section{Evaluation of antioxidant activity}

\section{DPPH free radical scavenging activity}

The ability of EPSNC2 to scavenge free radical was estimated using DPPH as a source of a free radical. The determination of antioxidant activity could be based on two methods: single electron transfer and hydrogen atom transfer (Gulcin, 2012; Tan and Lim, 2015). Polysaccharides have many functional groups such as hydroxyl groups which can quench free radical by hydrogen donation. EPSNC2 showed high powerful free radical scavenging activity in a dose-dependant manner with $\mathrm{IC}_{50}$ value $158.5 \mu \mathrm{g} / \mathrm{ml}$ at 120 minutes, as shown in Figure 4. This antioxidant activity of EPSNC2 was due to presence of hydroxyl groups in addition to a high percentage of uronic acid $(72.75 \%)$ containing carboxylic groups (Al-Sheraji et al., 2012; Wu et al., 2013). Ye et al., (2012) isolated and purified an acidic EPS which belonged to $\beta$-type heteropolysaccharide and has a pyran group from marine Pseudomonas PF-6. This EPS showed antioxidant activity against DPPH. El-Newary et al. (2017) noted that BAEPS

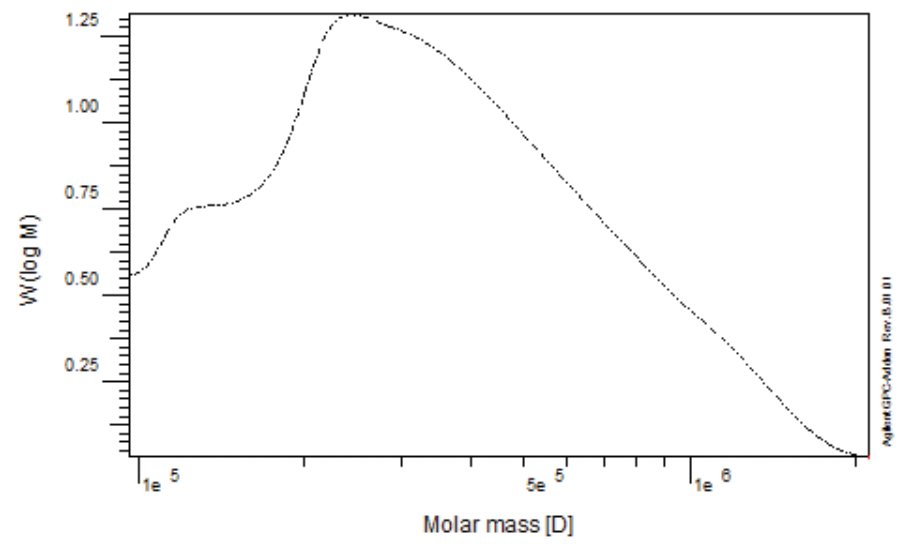

Figure 2. Mass average molar mass (Mw) of EPSNC2. an EPS has been isolated from Bacillus amyloliquefaciens 3MS 2017 could scavenge DPPH free radicals and the maximum activity was $99.39 \%$ at $1,000 \mu \mathrm{g} / \mathrm{ml}$. Streptomyces carpaticus produced an EPS which exhibited DPPH antioxidant activity with $\mathrm{EC}_{50}$ value $111 \mu \mathrm{g} / \mathrm{ml}$ (Selim et al., 2018).

\section{Hydrogen Peroxide scavenging activity}

Although the EPSNC2 showed antioxidant activity against hydrogen peroxide, its activity did not exceed $75.6 \%$ at $1,500 \mu \mathrm{g} / \mathrm{ml}$ after 60 minutes. s illustrates the antioxidant activity of EPSNC2 and $\mathrm{IC}_{50}$ value was estimated to be $501.2 \mu \mathrm{g} / \mathrm{ml}$ at 60 minutes. Besides the deleterious influences of $\mathrm{H}_{2} \mathrm{O}_{2}$, it is the source of hydroxyl free radical $\mathrm{OH}^{\bullet}$, the most potent and reactive free radical inside cells via Fenton and Haber-Weiss reactions (Fenton, 1894; Haber and Weiss, 1934). BAEPS which had been isolated by El-Newary et al. (2017) could scavenge $\mathrm{H}_{2} \mathrm{O}_{2}$ and the scavenging ability was found to be $61.72 \%$ at $100 \mu \mathrm{g} / \mathrm{ml}$ and was elevated progressively to $92.17 \%$ at $1,000 \mu \mathrm{g} / \mathrm{ml}$.

Ferric ion reducing power and ferrous ion metal chelating activity

It is supposed that the reducing power antioxidant activity of polysaccharides is due to the existence of free terminal electrophilic aldehyde and ketone groups which could reduce the metal ion. The $\mathrm{Fe}^{+3}$ of potassium ferricyanide was reduced to $\mathrm{Fe}^{+2}$ by EPSNC2 and Table 2 showed that RP increased in a dose-dependant manner. As observed by the metal chelating activity, $94.9 \%$ at $400 \mu \mathrm{g} / \mathrm{ml}$ and $98.5 \%$ at $1,000 \mu \mathrm{g} / \mathrm{ml}$ (Table 2). It is noteworthy that the hydroxyl and carboxyl groups found in EPSNC2 could interact with metal ions. Transition metal ions especially ferrous and cuprous ions are implicated in the formation of $\mathrm{OH}^{\bullet}$ via Fenton reaction and electron transferring via electron transport chain. Streptomyces violaceus MM72 producing an EPS showed strong metal chelating activities and moderate reducing activities (Manivasagan et al., 2013).

\section{In vitro anticancer activity against colon cancer cells}

To assess the EPSNC2 cytotoxic effect on tumor cells, we observed the cancer cell lines after exposure to EPSNC2 for 24 hours. Interestingly, EPSNC2 showed a significant cytotoxic effect on $\mathrm{CaCo}-2$ cell line without any effect on other cell lines (HepG2, MCF-7, and A-549) and the viability of CaCo-2 was remarkably decreased after EPSNC2 treatment in a dosedependant manner (Fig. 6). Whereas there was no effect until 125 $\mu \mathrm{g} / \mathrm{ml}$, the cytotoxic effect increased to $44.8 \%$ and $75 \%$ at 250 and $500 \mu \mathrm{g} / \mathrm{ml}$, respectively. $\mathrm{IC}_{50}$ was estimated to be $295.1 \mu \mathrm{g} / \mathrm{ml}$ as shown in Figure 7, which also showed that a strong correlation between the EPSNC2 concentration and the anticancer effect on CaCo2 cells $\left(R^{2}=0.9536, p=0.0043\right)$.

Many researchers found that polysaccharides had antitumor activity and their mode of action followed these mechanisms: i) stimulation and enhancement of immune system; ii) induction of apoptosis; iii) inhibition of angiogenesis; and iv) cell cycle arrest (Meng et al., 2016; Xu et al., 2016). EPS isolated from Lactobacillus acidophilus showed anticancer activity against two types of colon cancer cell lines HCT15 and CaCo-2 (Deepak et al., 2015). Zhou et al. (2017) reported that EPS116 from Lactobacillus plantarum NCU116 inhibits the 


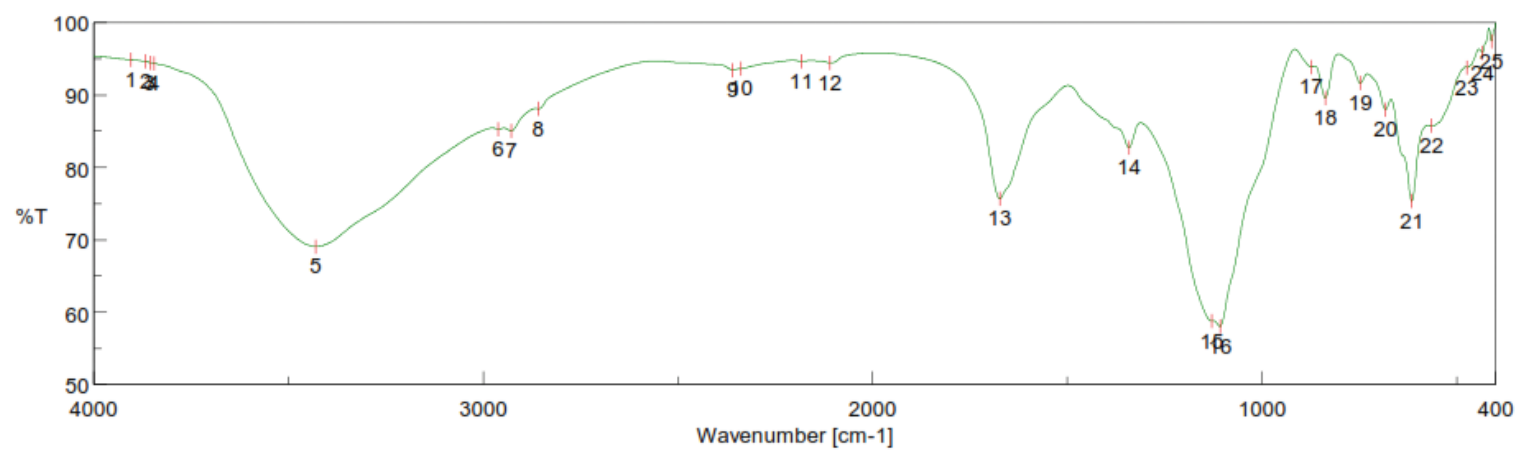

Figure 3. FT-IR spectrum of EPSNC2.

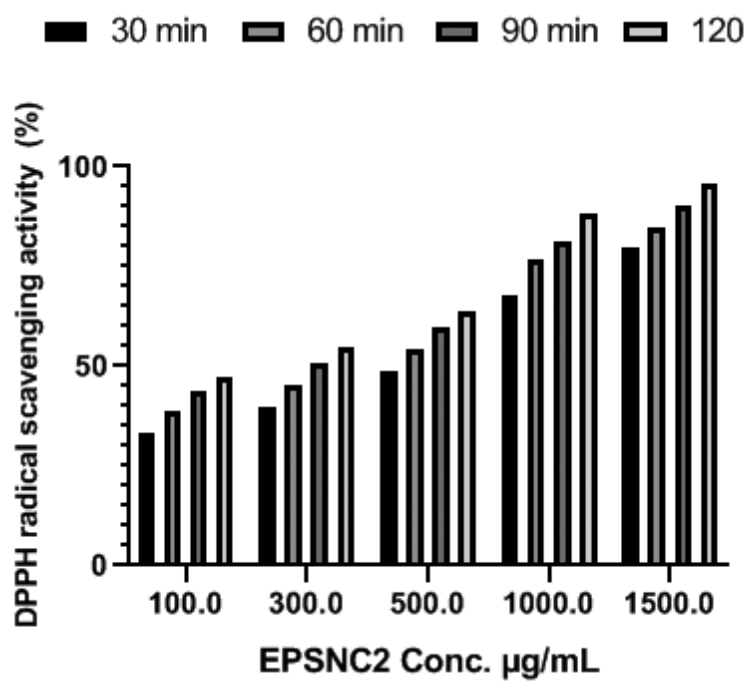

Figure 4. DPPH free radical scavenging activity of EPSNC2.

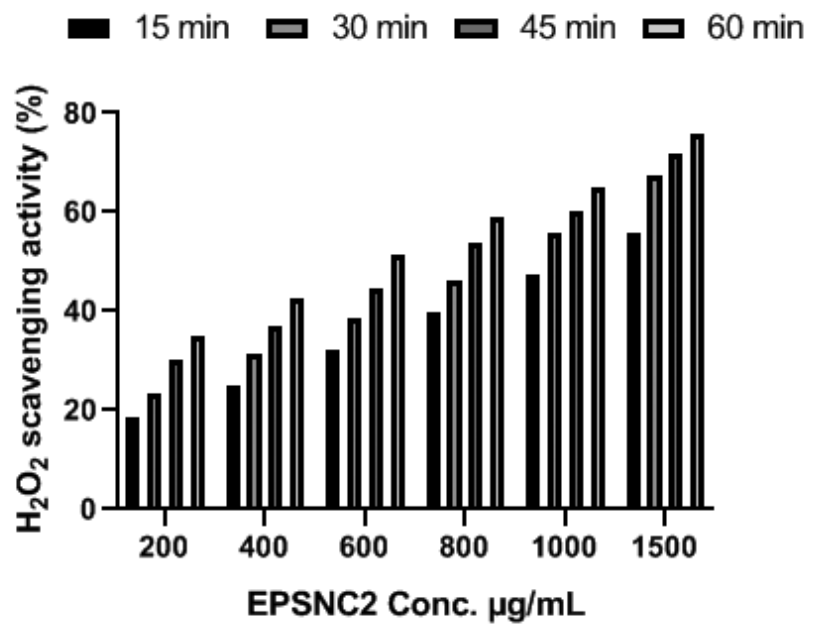

Figure 5. $\mathrm{H}_{2} \mathrm{O}_{2}$ scavenging activity of EPSNC2.

proliferation and survival of mouse colorectal carcinoma CT26 cells through induction of apoptosis via c-Jun, Fas/FasL pathways. Furthermore, the anticancer activity of EPS116 may be toll-like receptor (TLR)-2 dependent.
Table 2. RP and metal chelating activity of EPSNC2.

\begin{tabular}{ccc}
\hline EPSNC2 conc. $(\boldsymbol{\mu g} / \mathbf{m l})$ & RP activity & Metal chelating activity $\%$ \\
\hline 400 & 0.192 & 94.9 \\
600 & 0.2549 & 95.5 \\
800 & 0.2967 & 96.6 \\
1,000 & 0.3709 & 98.5 \\
\hline
\end{tabular}

EPSNC2 has high molecular weight with monosaccharide composition diversity so it is believed to exhibit more interactions with many different cell surface receptors especially on macrophages and dendritic cells such as TLRs, mannose-binding lectins, and C-type lectins which have carbohydrate recognition domain enhancing innate immune system and complement system against tumor (Brown and Gordon, 2005; Willment et al., 2005). High molecular weight polysaccharides cannot enter the cells but, instead they bind with cancer cell receptors controlling cell signaling and cellular transduction.

\section{Antiviral activity and EC50 determination}

Before assessment of antiviral activity, cytotoxicity of EPSNC2 was evaluated against African green monkey normal kidney epithelial cell line (VERO). The half-maximal cytotoxic concentration $\left(\mathrm{CC}_{50}\right)$ was $387.19 \mu \mathrm{g} / \mathrm{ml}$, while the maximum non-toxic concentration was $125 \mu \mathrm{g} / \mathrm{ml}$. The antiviral activity of EPSNC2 2 was $84.9 \%, 20.3 \%$, and $45.4 \%$ against $\mathrm{HSV}-1, \mathrm{HAV}$, and Coxsackie B4, respectively, at the non-toxic concentration $125 \mu \mathrm{g} /$ $\mathrm{ml}$. However, there was no antiviral activity against adenovirus at used EPSNC2 concentrations as shown in Figure 8. Figure 9 shows that the relationship between the logarithm of EPSNC2 concentration and its antiviral activity and the concentration which prevented the half-maximal viral cytopathic effect $\left(\mathrm{EC}_{50}\right)$ of HSV-1 was estimated to be $32.4 \mu \mathrm{g} / \mathrm{ml}$. It has been reported that the antiviral activity of polysaccharides follows one or more of these mechanisms: i) Direct Virucidal Action, ii) Inhibition of Viral Adsorption, iii) Inhibition of Virus Internalization and Uncoating, iv) Inhibition of Virus Transcription and Replication, and v) Improvement of Host Antiviral Immune Responses. Carlucci et al. (1997) reported that the sulfate-containing $\lambda$-carrageenan could bind with $\mathrm{HSV}$ virion inhibiting its replication and change the structure of the glycoproteins of HSV (Carlucci et al., 2002). Also, they demonstrated that $\lambda$-carrageenan and cyclized $\mu / \mathrm{l}$-carrageenan could interact with HSV-1 and HSV2 cell surface receptors preventing their adsorption and entry 

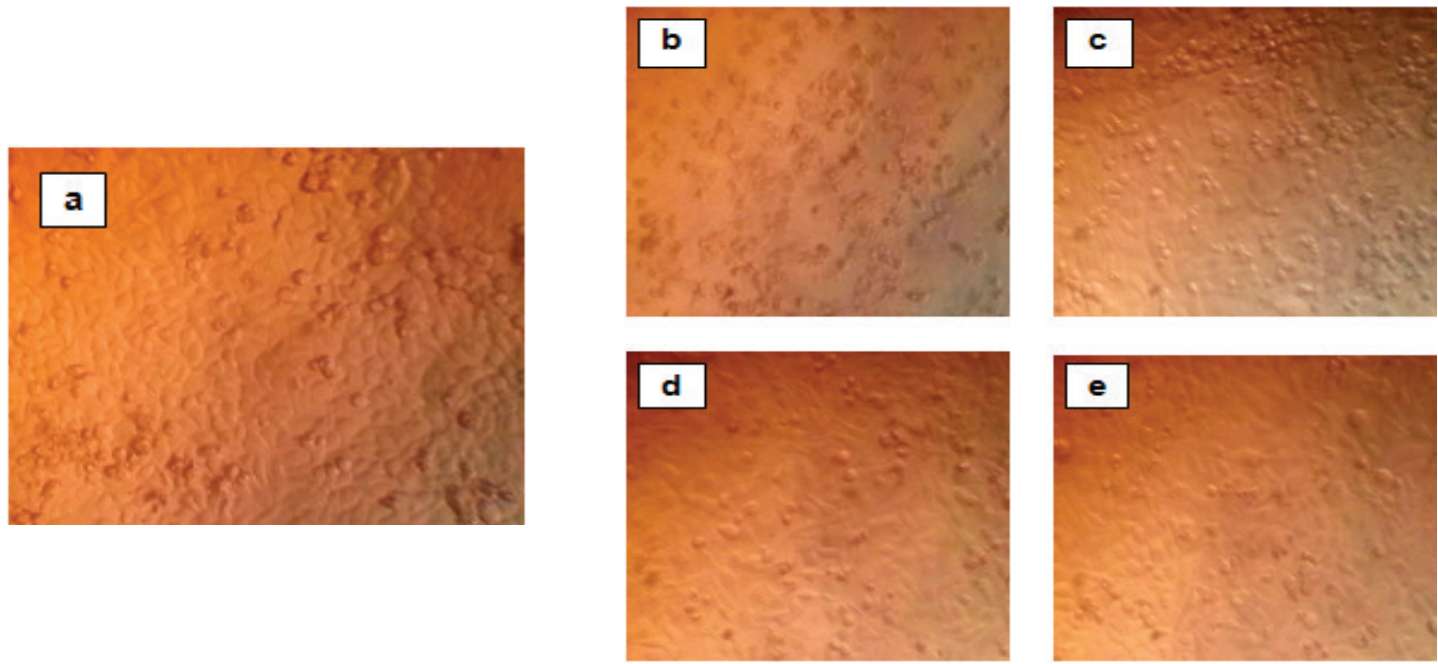

Figure 6. Anticancer effect against Caco-2 cell line. (a) Control; Caco-2 treated with EPSNC2 (b) $500 \mu \mathrm{g} / \mathrm{ml}$; (c) $250 \mu \mathrm{g} / \mathrm{ml}$; (d) 125 $\mu \mathrm{g} / \mathrm{ml}$; (e) $62.5 \mu \mathrm{g} / \mathrm{ml}$. Partial or complete loss of the confluent monolayer, rounding, shrinkage, and cell granulation were observed.

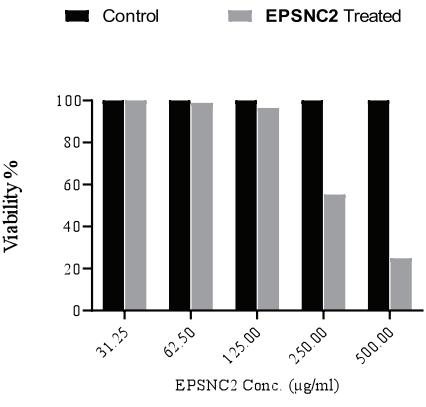

(A)

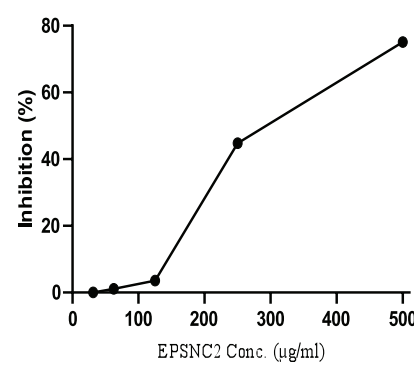

(B)
Figure 7. (A) Cytotoxicity (\%) of EPSNC2 against $\mathrm{CaCo}-2$ colon cancer cell line, (B) Correlation of Anticancer Activity. Significance: $p$ value $=0.0076^{* *}$.
(A)

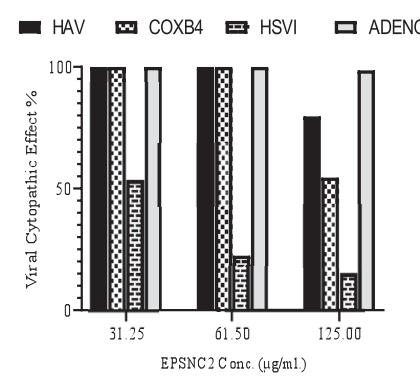

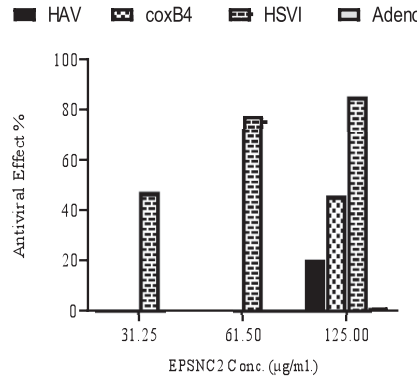

(B)
Figure 8. (A) Viral Cytopathic effect. (B) Antiviral activity of EPSNC2 against HAV, COXB4, HSV1, and ADENO viruses. Significance: $p$ value $=0.0048^{* *}$.

(Carlucci et al., 1997). Without any doubt, polysaccharides have potent antiviral activity against enveloped viruses rather than non-enveloped and EPSNC2 consistent with what was published previously (Ahmadi et al., 2015). Obviously, EPSNC2 contains a high content of glucuronic and galacturonic so; it can block the viral cell surface receptor preventing adsorption or interaction with HSV $\mathrm{gC}$ and/or gB glycoproteins preventing HSV $\mathrm{gC}$ and/

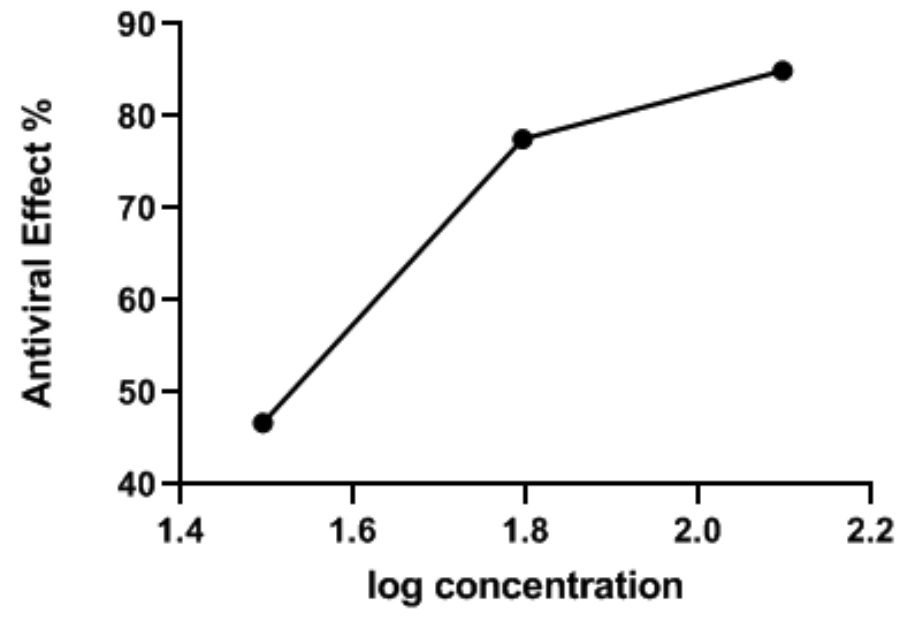

Figure 9. $\mathrm{EC}_{50}$ of $\mathrm{EPSNC} 2$ on $\mathrm{HSV}-1$.

or gB-heparan sulfate interaction via mimicking heparan sulfate proteoglycans.

\section{FINANCIAL SUPPORT}

None.

\section{CONFLICT OF INTEREST}

The authors declare that there are no conflicts of interest.

\section{REFERENCES}

Ahluwalia SS, Goyal D. Removal of heavy metals by waste tea leaves from aqueous solution. Eng Life Sci, 2005; 5:158-62.

Ahmadi A, Moghadamtousi SZ, Abubakar S, Zandi K. Antiviral potential of algae polysaccharides isolated from marine sources: a review. BioMed Res Int, 2015; 825203:10.

Akhtar J, Shukla D. Viral entry mechanisms: cellular and viral mediators of herpes simplex virus entry. FEBS J, 2009; 276(24): 7228-36.

Al-Sheraji AI, Manap MY, Mustafa S, Yusof RM, Hassan FA. Purification, characterization and antioxidant activity of polysaccharides 
extracted from the fibrous pulp of Mangifera pajang fruits. LWT-Food Sci Technol, 2012; 48(2):291-6.

Beshay U, Daba A, Gohar Y. Optimization of submerged culture conditions for exo-polysaccharides production by Streptomyces Nasri-UV 135 in bioreactor. J Microbial Biochem Technol, 2009; 1(1):43-6.

Brand-Williams W, Cuvelier ME, Berset C. Use of a free radical method to evaluate antioxidant activity. LWT Food Sea, 1995; 28:25-30.

Brock Neely W. Infrared spectra of carbohydrates. Advances in carbohydrate chemistry. Academic press Inc., New York, vol. 12, pp 13-33, 1957.

Brown GD, Gordon S. Immune recognition of fungal betaglucans. Cell Microbiol, 2005; 7:471-9.

Carlucci MJ, Pujol CA, Ciancia M, Noseda MD, Matulewicz MC, Damonte EB, Cerezo AS. Antiherpetic and anticoagulant properties of carrageenans from the red seaweed Gigartina skottsbergii and their cyclized derivatives: correlation between structure and biological activity. Int J Biol Macromol, 1997; 20:97-105.

Carlucci MJ, Scolaro LA, Damonte EB. Herpes simplex virus type 1variants arising afterselection with an antiviral carageenan: lack of correlation between drug susceptibility and syn phenotype. J Med Virol, $2002 ; 68: 92-8$

Cheng A, Wan F, Jin Wang J, Xu X. Nitrite oxide and inducible nitric oxide synthase were regulated by polysaccharides isolated from Glycyrrhiza uralensis Fisch. J Ethnopharmacol, 2008; 118:59-64.

Deepak V, Ramachandran S, Balahmar RM, Pandian SRK, Sivasubramaniam SD, Nellaiah H, Sundar K. In vitro evaluation of anticancer properties of exopolysaccharides from Lactobacillus acidophilus in colon cancer cell lines. In vitro cell. Dev Biol Anim, 2015; 52(2):163-73.

Dinis TC, Madeira VM, Almeida LM. Action of phenolic derivatives (acetaminophen, salicylate, and 5-aminosalicylate) as inhibitors of membrane lipid peroxidation and as peroxyl radical scavengers. Arch Biochem Biophys, 1994; 315(1):161-9?

Dodgson KS, Price RG. A note on the determination of the ester sulphate content of sulphated polysaccharides. Biochem J, 1962; 84(1):106.

El-Newary SA, Ibrahim AY, Asker MS, Mahmoud MG, El Awady ME. Production, characterization and biological activities of acidic exopolysaccharide from marine Bacillus amyloliquefaciens 3MS 2017. Asian Pac J Trop Med, 2017; 10(7):652-62.

Fenton HJH. Oxidation of tartaric acid in presence of iron. J Chem Soc Trans, 1894; 65:899-910.

Filisetti-Cozzi TM, Carpita NC. Measurement of uronic acids without interference from neutral sugars. Anal Biochem, 1991; 197(1):157-62.

Forman D, Ferlay J. The global and regional burden of cancer. In Stewart BW, Wild CP (eds.). World Cancer Report. The International Agency for Research on Cancer, World Health Organization, Geneva, Switzerland, pp 16-53, 2014.

Gardes M, Bruns TD. ITS primers with enhanced specificity for basidiomycetes application to the identification of mycorrhizae and rusts. Mol Ecol, 1993; 2(2):113-8.

Goodfellow M, Lacey J, Todd C. Numerical classification of thermophilic Streptomyces. J Gen Microbiol, 1987; 133:3135-49.

Gulcin I. Antioxidant activity of food constituents: an overview. Arch Toxicol, 2012; 86(3):345-91.

Haber F, Weiss J. The catalytic decomposition of hydrogen peroxide. Proc R Soc, 1934; 147:332-51.

Hayakawa M, Nonomura H. Vitamin agar, a new medium for the selective isolation of soil actinomycetes. J Ferment Technol, 1987; 65:501-9.

Jones SE, Paynich ML, Kearns DB, Knight KL. Protection from intestinal inflammation by bacterial exopolysaccharides. J Immunol, 2014; 192(10):4813-20.

Kavita K, Singh VK, Mishra A, Jha B. Characterisation and antibiofilm activity of extracellular polymeric substances from Oceanobacillus iheyensis. Carbohydr Polym, 2014; 101:29-35.

Kutzner HJ. Methoden zur untersuchung von Streptomyceten und einigen anderen actimomyceten. Teilsammlung Darmstadt am Institut für Mikrobiologie der Technishen Hochschule, TU Darmstadt, Germany, pp 1-154, 1967.

Lillo L, Cabello G, Cespedes CL, Caro CA, Perez J. Structural studies of the exopolysaccharide produced by a submerged culture of entomopathogenic fungus Metarhizium anisopliae. Boletín Latinoamericano Y Del Caribe De Plantas Medicinales Y Aromáticas, 2014; 13:359-65.

Liu C, Lu J, Lu L, Liu Y, Wang F, Xiao M. Isolation, structural characterization and immunological activity of an exopolysaccharide produced by Bacillus licheniformis 8-37-0-1. Bioresour Technol, 2010; 101(14):5528-33.

Manivasagan P, Sivasankar P, Venkatesan J, Senthilkumar K, Sivakumar K, Kim S. Production and characterization of an extracellular polysaccharide from Streptomyces violaceus MM72. Int J Biol Macromol, 2013; 59:29-38.

Meng X, Liang HB, Luo LX. Antitumor polysaccharides from mushrooms: a review on the structural characteristics, antitumor mechanisms and immunomodulating activities. Carbohyd Res, 2016; 424:30-42.

Mossman T. Rapid colorimetric assay for cellular growth and survival: application to proliferation and cytotoxicity assays. J Immunol Methods, 1983; 65:55-65.

Oyaizu M. Studies on products of browning reaction. J. Acad. Nutr. Diet, 1986; 44(6):307-15.

Pauwels R, Balzarini J, Baba M, Snoeck R, Scols D, Herdewijn P, Desmyter J, De Clercq E. Rapid and automated tetrazolium-based calorimetric assay for the detection of anti-HIV compounds. J Virol Methods, 1988; 20:309-21.

Patel AK, Michaud P, Singhania RR, Soccol CR, Pandey A. Polysaccharides from probiotics: new developments as food additives. Food Technol Biotechnol, 2010; 48(4):451-63 .

Randall RC, Phillips GO, Williams PA. Fractionation and characterization of gum from Acacia senegal. Food hydrocoll, 1989; 3(1):65-75.

Rincão VP, Yamamoto KA, Ricardo NMPS, Soares SA, Meirelles LDP, Nozawa C, Linhares REC. Polysaccharide and extracts from Lentinula edodes: structural features and antiviral activity. Virol J, 2012; 9:37.

Ruch RJ, Crist KA, Klaunig JE. Effects of culture duration on hydrogen peroxide-induced hepatocyte toxicity. Toxicol Appl Pharmacol, 1989; 100(3):451-64.

Sarkar S, Horn G, Moulton K, Oza A, Byler S, Kokolus S, Longacre M. Cancer development, progression and therapy: An epigenetic overview. Int J Mol Sci, 2013; 14:21087-113.

Selim MS, Amer SK, Mohamed SS, Mounier MM, Rifaat HM. Production and characterisation of exopolysaccharide from Streptomyces carpaticus isolated from marine sediments in Egypt and its effect on breast and colon cell lines. J Appl Pharm Sci, 2018; 8:1-11.

Shene C, Canquil N, Bravo S, Rubilar M. Production of the exopolysacchzrides by Streptococcus thermophilus: effect of growth conditions on fermentation kinetics and intrinsic viscosity. Int J Food Microbiol, 2008; 124(3):279-84.)

Shirling EB, Gottlieb D. Methods for characterization of Streptomyces species. Inter J Sys Evol Microbiol, 1966; 16:313-40.

Sun Y, Sun T, Wang F, Zhang J, Li C, Chen X, Li Q, Sun S. A polysaccharide from the fungi of Hauier exhibits anti-tumor potential and immunomodulatory effects. Carbohyd Polym, 2013; 92:577-82.

Sutherland IW. Microbial exopolysaccharides - structural subtleties and their consequences. Pure Appl Chem, 1997; 69:1911-7.

Szabó IM, Marton M, Buti I, Fernandez C. A diagnostic key for the identification of "species" of Streptomyces and Streptoverticillium included in the International Streptomyces Project. Acta Bot Acad Sci Hungaricae, 1975; 21:387-418.

Tan JBL, Lim YY. Critical analysis of current methods for assessing the in vitro antioxidant and antibacterial activity of plant extracts Food Chem, 2015; 172:814-22.

Tang Y, Dong W, Wan K, Zhang L, Li C, Zhang L, Liu N. Exopolysaccharide produced by Lactobacillus plantarum induces maturation of dendritic cells in BALB/c mice. PLoS One, 2015; 10(11):e0143743. 
Tresner HD, Backus EJ. System of color wheels for streptomycete taxonomy. Appl Microbiol, 1963; 11:335-8.

Vijayabaskar P, Babinastarlin S, Shankar T, Sivakumar T, Anandapandian K. Quantification and characterization of exopolysaccharides from Bacillus subtilis (MTCC 121). Adv Biol Res, 2011; 5:71-6.

Waksman SA. The actinomycetes. Classification, identification and descriptions of genera and species. The Williams and Wilkins Co., Baltimore, MD, vol. 1, pp 1-363, 1961.

Whitley RJ, Roizman B. Herpes simplex virus infections. Lancet, 2001; 357:1513-8.

Willment JA, Marshall AS, Reid DM, Williams DL, Wong SY, Gordon S, Brown GD. The human beta-glucan receptor is widely expressed and functionally equivalent to murine Dectin-1 on primary cells. Eur J Immunol, 2005; 35:1539-47.

Wu H, Min T, Li X, Li L, Lai F, Tang Y, Yang X. Physicochemical properties and antioxidant activities of acidic polysaccharides from wampee seeds. Int J Biol Macromol, 2013; 59:90-5.

Xie JH, Xie MY, Nie SP, Shen MY, Wang YX, Li C. Isolation, chemical composition and antioxidant activities of a water-soluble polysaccharide from Cyclocarya paliurus (Batal.) Iljinskaja. Food Chem, 2010; 119:1626-32.

$\mathrm{Xu} \mathrm{H}$, Zou SW, Xu XJ. Anti-tumor effect of ß-glucan from Lentinus edodes and the underlying mechanism. Sci Rep, 2016; 6:28802.
Ye S, Liu F, Wang J, Wang H, Zhang M. Antioxidant activities of an exopolysaccharide isolated and purified from marine Pseudomonas PF-6. Carbohydr Polym, 2012; 87:764-70.

You J, Dou L, Yoshimura K, Kato T, Ohya K, Moriarty T, Emery $\mathrm{K}$, Chen C, Gao J, Li G, Yang Y. A polymer tandem solar cell with $10.6 \%$ power conversion efficiency. Nat Commun, 2013; 4:1446.

Zhou X, Hong T, Yu Q, Nie S, Gong D, Xiong T, Xie M. Exopolysaccharide from Lactobcillus Plantarum NCU116 induce c-Jun dependant Fas/FasL- mediated apoptosis via TLR2 in mouse intestinal epithelial cancer cells. Sci Rep, 2017; 7(1):14247.

\section{How to cite this article:}

El Awady ME, Eldin MAN, Ibrahim HM, Al Bahnasy ME, Aziz SHA. In vitro evaluation of antioxidant, anticancer, and antiviral activities of exopolysaccharide from Streptomyces hirsutus NRC2018. J Appl Pharm Sci, 2019; 9(11):010-018. 